\title{
Analysis of qualitative and quantitative indicators of milk production and processing at the enterprises of the Akmola region
}

\author{
Zhanara Nurtayeva
}

\begin{abstract}
The primary tasks are the development of the agro-industrial complex of the Republic of Kazakhstan and the provision of high-quality products to the population. The Akmola region is one of the country's most developed agricultural and industrial regions. The assessment of qualitative and quantitative indicators of milk production and processing in the Akmola region reflects the development dynamics of the dairy industry of the country and the main problems that need to be solved; therefore, research on this issue is relevant. The purpose of the study was to analyse the quantitative and qualitative indicators of milk production and processing at the enterprises of the Akmola region, review research on the development of formulations based on the raw materials of the area, and study factors affecting the quality of dairy products. The main method used in the study was the analysis of the suitability of milk of the Akmola region as a raw material for producing cheese fermented milk. It was found that, in general, the quality of milk of the Akmola region in terms of fat, protein, minerals, and lactose, the fatty-acid composition of milk fat, the content of somatic cells is good. The specificity of the region, which consists in the fact that most of the raw materials for milk processing plants are supplied by private farms, leads to the variability of microbiological indicators of milk and the content of somatic cells, which limits the use of milk in the production of certain types of cheese. It was concluded that there is a necessity in the development of new recipes, considering the characteristics of raw and powdered milk produced in the Akmola region, which will increase the range of high-quality dairy products, which will be distributed within the country and for export.
\end{abstract}

Keywords: cow's milk, protein, fat content, fermented milk products, agriculture, milk yield

\section{INTRODUCTION}

An indispensable component of economic security is food security. In food supply, import substitution covers a complex of industries related to agriculture [1]. For the development of agriculture in the Akmola region, subsidies are allocated in livestock breeding and improving the productivity and quality of livestock products, reducing the cost of milk production [2]. In 2020, 5047 heads were purchased at the expense of the republican and local budgets, and breeding work was underway. Subsidising the production and sale of milk in 2020 amounted to $29,337.56$ tons, 398,296 tons of mare's milk, while in $2019-18,297.1$ and 314.6 tons. The growth in milk production to the level of 2019 with the plan of $1.2 \%$ was $1.7 \%(141.7 \%)$. The indicator was exceeded due to an increase in the commissioning of new commodity dairy farms and an increase in existing production farms. Subsidising the costs of processing enterprises for the purchase of milk covered 19 thousand tons of milk, for the production of butter -809.9 tons, hard cheese -65.1 tons [3].

Agriculture is one of the leading and dynamically developing sectors of the regional economy. Work is underway to attract investment in the industry. In 2020, more than 62 billion tenges were allocated to agriculture, which is $18.1 \%$ higher than in 2019. In addition to that, all funds are private investments. The modernisation of the dairy processing plant LLP (Limited Liability Partnership) "Gormolzavod" (total capacity - 150 tons per day), the products of which are the brand of the region, the creation of a feed mill LLP "MMK "Ayan" Arshaly district, with a capacity of 28 thousand tons per year. In the Birzhan-sal area, the construction of a breeding reproducer 
for 4.5 thousand heads of cattle has been completed - Burabay Astyq LLP, in Kokshetau - the structure of a fattening site of Bibord LLP, with a capacity of 5 thousand heads. Eighteen dairy farms have been established. As a result, 56 specialised enterprises with total livestock of 12.5 thousand heads are currently engaged in milk production in the region. The capacity of fattening sites for the one-time maintenance of cattle has been increased up to 36.5 thousand heads [4]. There are 15 dairy production enterprises in the Akmola region, with a production capacity of 146.8 thousand tons of milk per year (Table 1).

Table 1 Milk processing enterprises of Akmola region.

\begin{tabular}{lcc}
\hline Name of the district & Enterprise name & Capacity, tons/year \\
\hline Akkol & Eco milk LLP & 25000 \\
Arshaly & Izhevskiy PC (production cooperative) & 1800 \\
& Voskhod 2004 LLP & 3600 \\
Burabay & Yesil-Agro LLP & 3500 \\
Esil & Esilskiy butter-making plant LLP & 3050 \\
Zhaksy & Aybat LLP & 3050 \\
Zharkain & Milk Project LLP & 900 \\
Zerendi & Agrofirma Rodina LLP & 18000 \\
& Maksimovsky dairy plant LLP & 16000 \\
Tselinograd & Mstana Onim JSC (Joint Stock Company) & 2100 \\
Shortandy & Molochny 2 APC & 3050 \\
Kokshetau & Gormolzavod LLP & 3600 \\
& Moloko Sinegorye LLP & 7300 \\
& Natizhe LLP & 45800 \\
\hline
\end{tabular}

Note: Source [5].

Considering that about $80 \%$ of the total milk production takes place in households, to develop the region's dairy industry, the Yrys programme is being implemented in the region within the framework of the Agribusiness 2020 programme for the development of a network of family dairy farms. Farmers had the opportunity to purchase a breeding stock of dairy cattle, small cattle (goats), the necessary machinery and equipment. Work on organizing the purchase of milk from the population is being carried out to load the production capacities of existing milk processing enterprises [6].

\section{Scientific Hypothesis}

The development of dairy production in the Akmola region is a priority and contributes to ensuring the food security of the Republic of Kazakhstan. The purpose of the study was to analyse the quantitative and qualitative indicators of milk production and processing at the enterprises of the Akmola region, review research on the development of formulations based on the raw materials of the region, and study factors affecting the quality of dairy products. The hypothesis of research work hinged on the assumptions that the quality of milk of the Akmola region in terms of fat, protein, minerals, and lactose, the fatty-acid composition of milk fat, the content of somatic cells is good.

\section{MATERIAL AND METHODOLOGY \\ Data Collection}

This article is an overview of the research on the production of milk and dairy products in the territory of the Akmola region. The review includes statistical reports provided by the Department of Agriculture of the Akmola region. The analysis of the suitability of milk of the Akmola region as a raw material for producing cheese fermented milk products was conducted. References are given to the studies on developing formulations of dairy products in the region using cow's milk and its substitute - goat's milk. To produce high-quality dairy products, processors need high-quality raw milk, which is defined as:

- full in composition (protein and fat content within the norm);

- without foreign tastes and smells;

- without detectable residues of medicinal substances, added water, or other impurities;

- with a low total number of bacteria;

- with a low number of somatic cells [7]. 
Typically, the processor monitors the milk supply to the dairy plant to ensure that quality raw milk will be produced. The quality of raw milk is most often considered in terms of the potential impact on the quality of the processed product, which depends on the number of somatic cells and the total number of bacteria. High levels of somatic cells and bacteria are associated with increased activity of enzymes that damage milk components and lead to product defects. The enzymes related to increased content of somatic cells and bacteria to influence the quality of dairy products depends on several factors. These include the amount of enzyme, specificity, heat resistance, processing and storage temperature, $\mathrm{pH}$ (pondus Hydrogenii), humidity, and the presence of inhibitors and activators. The potential effect will vary depending on the enzyme, product, and conditions. In the United States of America, the regulatory limits on the number of somatic cells for class A milk production is 750000 $\mathrm{CFU} / \mathrm{mL}$ and on the total bacterial content - 100,000 CFU (colony-forming units)/mL [8].

\section{Description of the Experiment}

A brief overview of the main factors that affect the quantitative and qualitative indicators of milk is also conducted. These include the breed of animals, maintenance conditions, seasonality, conditions for the delivery of milk to processing plants. The leading indicators of milk that affect its technological quality for different types of dairy products are considered.

Most milk producers strive to meet stricter requirements, which is often associated with promoting quality and the payment of "allowances" offered by cooperatives or other buyers of raw milk. The increased payment by processors of higher-quality raw milk is the ability to process such milk more efficiently, obtaining products of higher quality and with a longer shelf life. Since the product's characteristics ultimately depend on the quality of milk, there is a great interest in identifying the fundamental relationship of the factors of milk production that influence its composition. The overall purpose of such studies is to increase the profitability of milk processing operations [9]. Since many milk and dairy producers are concentrated in the Akmola region, the analysis of qualitative and quantitative indicators of milk and dairy products of the region and factors that affect these indicators is relevant to obtain an overall picture of the state of the dairy industry of the country.

\section{Statistical Analysis}

All determinations were conducted in triplicate or more, and all results were calculated as mean \pm standard deviation (SD). The threshold of reliability of the obtained data was designated as $p<0.05$. Microsoft Excel produced the statistical analysis data.

\section{RESULTS}

Milk production in the Akmola region has a steady tendency to increase (Table 2).

Table 2 Cow's milk production in all categories of farms of Akmola region (thousand tons).

\begin{tabular}{|c|c|c|c|c|c|c|c|c|}
\hline \multirow{2}{*}{ Year } & \multirow{2}{*}{2015} & \multirow{2}{*}{2016} & \multirow{2}{*}{2017} & \multirow{2}{*}{2018} & \multirow{2}{*}{2019} & \multirow{2}{*}{$\begin{array}{c}2015- \\
2019\end{array}$} & \multicolumn{2}{|c|}{$2019, \%$} \\
\hline & & & & & & & 2015 & 2018 \\
\hline $\begin{array}{l}\text { Gross milk } \\
\text { yield, total }\end{array}$ & 359.0 & 377.0 & 383.8 & 385.8 & 396.1 & 1901.7 & 110.3 & 102.7 \\
\hline $\begin{array}{l}\text { Agricultural } \\
\text { enterprises }\end{array}$ & 41.1 & 66.9 & 71.3 & 70.5 & 77.0 & 326.8 & 187.5 & 109.3 \\
\hline $\begin{array}{l}\text { Individual } \\
\text { entrepreneurs, } \\
\text { peasant or } \\
\text { husbandry } \\
\text { farms }\end{array}$ & 14.3 & 17.2 & 18.9 & 19.3 & 19.9 & 89.6 & 138.9 & 103.2 \\
\hline $\begin{array}{l}\text { Households of } \\
\text { the population }\end{array}$ & 303.6 & 292.9 & 293.6 & 296.0 & 299.2 & 1485.3 & 98.5 & 101.1 \\
\hline
\end{tabular}

For five years (2015 - 2019), 1901.7 thousand tons of milk were produced in all categories of farms in the Akmola region, including in agricultural enterprises - 326.8 thousand tons (17.2\%), peasant or husbandry farms $-89.6(4.7 \%)$, households -1485.3 thousand tons $(78.1 \%)$. During the analysed period, milk production increased by $10.3 \%$, including in agricultural enterprises $-87.4 \%$, individual entrepreneurs and peasant or husbandry farms - by $39.2 \%$, in households, milk production decreased by $1.5 \%$. The largest volume of milk for the analysed period was produced in all categories of farms in 2019. It amounted to 396.1 thousand tons, in agricultural enterprises in 2019 - 77 thousand tons, in individual entrepreneurs and peasant or husbandry farms in $2019-19.9$ thousand tons. The main milk producers for the analysed period are the farms of Zerendi - 257.2 thousand tons 
or $13.5 \%$ of the total production, Ereymentau -182.8 thousand tons $(9.6 \%)$, Burabay -177.4 thousand tons (9.3\%), Tselinograd - 166.6 thousand tons $(8.8 \%)$ districts. The main producers of milk are the households of the population. For five years, their share in the structure of milk production averaged $78 \%$, in agricultural enterprises - $17 \%$, in individual entrepreneurs and peasant or farm farms $-5 \%[\mathbf{1 0}]$.

During the analysed period, there was an increase in the average milk yield per dairy cow for all categories of farms, which was $3050 \mathrm{~kg}$. In 2019, the average milk yield per dairy cow was $3118 \mathrm{~kg}, 2.2 \%$ higher than the analysed period. The highest level of milk yield in five years $-4158 \mathrm{~kg}$ was observed in agricultural enterprises of the region. This is explained by the fact that agrarian enterprises have the opportunity to purchase highly productive dairy cattle, which most peasant or husbandry farms do not yet have. Over the past five years, high milk yields per dairy cow have been noted in all categories of farms in Tselinograd (3665 kg), Akkol (3400 kg), and Burabay (3211 kg) districts [10]. In 2020, milk production in the Akmola region increased by $1.7 \%$, to 402.7 thousand tons, dairy products - by $6.4 \%$ (to 94.9 thousand tons) [4]. The workload of milk processing enterprises for the period from January to July 2021 amounted to $66.4 \%$ (in $2020-68.3 \%$ ), the volume of processed milk production amounted to 48.7 thousand tons, there was a decrease of $2.8 \%$ to the same level in 2020,599 tons of cream butter produced with an increase of $12.8 \%$, cheese and cottage cheese - 684 tons, fermented milk products -3.2 thousand tons with an increase of $0.03 \%$ [11].

An analysis of the state of the dairy industry in Kazakhstan shows that the main problem remains the underdevelopment of the raw material base. To create a raw material base, processing enterprises in the region are opening stationary milk reception points to increase the volume of milk purchases in private subsidiary farms. One of the main factors influencing the change in dairy production is the number of cows for dairy purposes. It is impossible to ensure sustainable development of processing production without a stable raw material base [8]. The number of cows in the Akmola region is increasing. As part of the development of dairy farming this year, it is planned to create 19 dairy farms with the acquisition of 4.1 thousand heads, while seven farms for 911 heads were created [11]. Cattle of the best breeds have been imported into Kazakhstan and continue to be imported. The study of imported animals' adaptation and descendants is of great scientific and industrial importance - the object of the study [12] was the first-calf heifers of the Holstein breed of individual generation, obtained from Canadian Holsteins in the conditions of the Agrofirm "Rodina" LLP of the Akmola region. The animals were in a facility with loose keeping, mobile distribution of feed mixture, and milking on a Carousel-type installation. The animals" diet consisted of a feed of individual production (corn silage, wheat hay) mixed feed for cattle. It was designed to receive six thousandth milk yields of first-calf heifers.

The milk productivity of the Holstein first-calf heifers of individual generations was studied compared to their mothers imported from Canada. The milk yield of the first-calf heifers was $6488 \mathrm{~kg}$, which is $139 \mathrm{~kg}$ less than mothers. The content of fat, protein, and minerals in the milk of offspring is slightly higher than that of mothers (3.64\% and 3.60\% fat content, $3.08 \%$ and $3.03 \%$ protein, respectively). The resulting offspring is characterised by an increased haemoglobin content (148 g.. $\mathrm{L}^{-1}$ versus 136 g.L $\mathrm{L}^{-1}$ in their mothers), $\beta$-globulins. The resistance of farm animals to harmful environmental factors, particularly to infectious diseases, was evaluated. Cellular defence factors were at the level of $55 \%$, with the aggressiveness of neutrophils at $8.8 \%$, in mothers $-54 \%$. Humoral protection factors were higher in first-calf heifers: bactericidal activity $74.3 \%$, lysozyme activity $9.3 \%$, in mothers these indicators were $71.5 \%$ and $7.4 \%$. The data obtained indicate a satisfactory adaptation of Holstein animals in the conditions of the north of Kazakhstan [12]. The study [13] examined the availability of protein and energy in the diet of dairy cows of the Akmola region and its impact on productivity. As an indicator of the quality of cow feeding, the urea content in milk was used, which generally should be within $15-30 \mathrm{mg} \%$. A high level of urea concentration can indicate an excess of protein and a lack of easily digestible carbohydrates necessary for the vital activity of the microflora of the rumen.

Conversely, a decrease in urea in milk can be caused by low protein levels and an excess of carbohydrates in the diet. Low urea content in milk can cause a decrease in productivity, problems with animal fertility, the occurrence of acidosis. The increased content of urea, in turn, increases the risks of diseases of reproductive function, metritis, lameness, ketosis, liver diseases. The indicators of milk productivity and milk composition of dairy herds of the Akmola region of the Republic of Kazakhstan obtained in the study [13] are presented in Table 3. The urea content in the milk of the dairy herd of Agrofirma Rodina LLP was $34.25 \pm 0.29 \mathrm{mg} \%$, which indicates that the upper threshold value was exceeded. It was confirmed that the amount of protein exceeded $7.9 \%$ compared to the standards of feeding dairy cattle. In Yesil-Agro LLP, the urea content in milk was $11.7 \mathrm{mg} \%$, with a lower threshold value of $15 \mathrm{mg} \%$. This was a consequence of an excess of carbohydrates and a lack of protein in the diet of dairy cows, which in the future could lead to a decrease in productivity and impaired reproductive function. 
Table 3 Indicators of milk productivity and milk composition of dairy herds of the Akmola region of the Republic of Kazakhstan.

\begin{tabular}{lcccc}
\hline \multicolumn{1}{c}{ Name of the farm } & $\begin{array}{c}\text { Daily milk yield, } \\
\mathbf{~ k g}\end{array}$ & $\begin{array}{c}\text { Mass fraction of } \\
\text { fat, } \%\end{array}$ & $\begin{array}{c}\text { Mass fraction of } \\
\text { protein, } \%\end{array}$ & Urea, $\mathbf{~ m g \%}$ \\
\hline Agrofirma Rodina LLP & $7446 \pm 56.9$ & 4.44 & 3.63 & 34.25 \\
Yesil-Agro LLP & $7456 \pm 86.0$ & 3.54 & 3.39 & 11.7 \\
\hline
\end{tabular}

The study by A. Zh. Khastaeva, V. S. Zhamurova, L. A. Mamaeva, A. T. Kozhabergenov, N. Zh. Karimov, K. M. Muratbekova [14] investigated the influence of animal breed and season on the physicochemical characteristics of milk. The milk of the Holstein breed of cows of Astana Onim JSC of the Akmola region of Kazakhstan was analysed. Holstein cows in autumn had the highest fat content $-3.8 \%$ and the highest protein content $-3.3 \%$. Physicochemical indicators of milk quality for the lactation period of 305 days are presented in Table 4.

Table 4 Physicochemical and microbiological indicators of milk by season.

\begin{tabular}{lcccc}
\hline Season & $\begin{array}{c}\text { Mass fraction of fat, } \\
\text { \% }\end{array}$ & $\begin{array}{c}\text { Mass fraction of } \\
\text { protein, } \%\end{array}$ & $\begin{array}{c}\text { Somatic cell content, } \\
\text { thousand/(cm }\end{array}$ & Acidity, ${ }^{\mathbf{3}} \mathbf{T}$ \\
\hline Spring & 3.70 & 3.18 & 260.11 & 16.9 \\
Summer & 3.73 & 3.17 & 167.96 & 18.0 \\
Autumn & 3.80 & 3.30 & 282.77 & 17.0 \\
Winter & 3.64 & 3.22 & 343.92 & 16.9 \\
\hline
\end{tabular}

Note: Source [14]

The seasonal dynamics of the mass fractions of 16 major fatty acids in milk fat is presented in Table 5 . The most common fatty acids were $\mathrm{C} 16: 0$, the sum of the isomers $\mathrm{C} 18: 1, \mathrm{C} 18: 0$, and $\mathrm{C} 14: 0$. At the expected levels, shortand medium-chain saturated fatty acids (SFA), such as C4:0, C6:0, C8:0, C10:0, and C12:0, were present at the expected levels. In spring and summer, relatively high content of C4:0 butyric acid was observed in milk, which creates the taste of dairy products. Among monounsaturated fatty acids (MUFA), C18:1 isomers were the main components. In general, the remaining percentage of monounsaturated and polyunsaturated fatty acids (PUFA) in the total milk fat of Holstein cows was considerably higher than in the milk of Simmental cows. The percentage of 3-polyunsaturated fatty acids was higher in the samples of the Simmental breed $(1.06 \%$ and $1.17 \%$ versus $0.97 \%$ and $0.8 \%$ ) in summer and winter compared to the Holstein breeds; however, the percentage of 3polyunsaturated fatty acids in the spring and autumn periods in the Holstein breed was $1.29 \%$ and $1.01 \%$ compared to $0.42 \%$ and $0.67 \%$. In spring, summer and autumn, the percentage of 6-polyunsaturated fatty acids $(3.84 \%$; $3.84 \%$; $3.6 \%$ vs $3.04 \% ; 2.49 \%$ and $2.46 \%$ ) was higher in the Holstein breed than in the Simmental breed [14].

The study [15] developed a technology for cheese production by thermal acid deposition from the milk of the Akmola region. Product developments were conducted at Milk Project LLP. The composition of milk, the absence of antibiotics, chemical and microbiological stability are essential requirements for the raw materials in cheese production by thermal acid deposition. The rennet capacity of milk for thermoacid coagulation cheese is not as important as for hard cheese. According to the chemical composition, milk with a mass fraction of protein of at least $3 \%$ and a sufficient mass fraction of fat was selected. The stability of milk in protein was about $91 \%$, and in fat $-75 \%$. Milk of this quality may well be used for the production of cheese by thermal acid deposition. At LLP "Scientific and Production Association "Innovator" Kosshi, Akmola region, formulations of fermented milk products with extruded grain bases from buckwheat, millet, lentils, and chickpeas with two versions of the milk base - milk with a fat content of $2.5 \%$ and $3.2 \%$ were developed [16]. According to physical and chemical parameters, all samples met the standard requirements for fermented milk products ST RK 1733-2015 "Milk and dairy products. General technical conditions" [17], according to safety indicators - within the requirements of the Technical Regulations of the Customs Union "On the safety of milk and dairy products" [18].

The study [19] developed a technology for producing fermented milk products from powdered milk produced at the enterprises of the Akmola region using sour whey. Milk powder and sour whey were combined in certain proportions; the resulting raw materials were exposed to ultrasound with simultaneous heating. Then fermentation was carried out using different types of starter cultures. The optimal technology was chosen to analyse the physicochemical and organoleptic characteristics of the resulting yoghurt. In the Akmola region, research is underway to develop recipes for products from other types of milk, for example, goat's milk. 
Table 5 Fatty acid composition of milk (\%) of Holstein breed of cows of Astana Onim JSC of Akmola region, depending on the season.

\begin{tabular}{lcccc}
\hline \multicolumn{1}{c}{ Fatty acid } & Spring & Summer & Autumn & Winter \\
\hline C4:0 & 3.29 & 3.66 & 3.27 & 2.83 \\
C6:0 & 1.78 & 1.88 & 1.58 & 1.78 \\
C8:0 & 1.16 & 1.48 & 1.23 & 1.27 \\
C10:0 & 3.05 & 2.95 & 2.08 & 2.93 \\
C10:1 & 0.29 & 0.34 & 0.26 & 0.30 \\
C12:0 & 3.11 & 3.11 & 2.71 & 0.31 \\
C14:0 & 9.99 & 11.29 & 10.03 & 11.03 \\
C14:1 & 1.23 & 1.18 & 1.29 & 1.12 \\
C16:0 & 29.29 & 28.06 & 28.27 & 2.76 \\
C16:1 & 2.28 & 1.99 & 2.09 & 9.94 \\
C18:0 & 9.84 & 11.32 & 9.02 & 26.17 \\
C18:1 & 25.14 & 23.61 & 29.25 & 2.91 \\
C18:2 & 3.84 & 3.84 & 3.60 & 0.80 \\
C18:3 & 1.29 & 0.90 & 1.01 & 0.22 \\
C20:0 & 0.20 & 0.15 & 0.13 & 0.09 \\
C22:0 & 0.09 & 0.10 & 0.07 & 5.47 \\
Other & 4.13 & 4.16 & 4.09 & \\
\hline
\end{tabular}

Note: Source [14].

The analysis of preferences of dairy consumers in the Akmola region showed that $81.5 \%$ of 417 respondents prefer dairy products from cow's milk, 10.1\% - from mare's milk (koumiss), $6 \%$ prefer goat products (fermented milk, cheese), $2.4 \%$ - from sheep's milk. In addition to that, the majority of respondents in rural areas independently produce dairy products [20]. The use of goat's milk in the production of fermented milk drinks offers broad prospects for reducing the shortage of cow's milk, using existing technological equipment, and developing new fermented milk products. The use of ozonation of goat's milk as a modern processing method allows eliminating tastes and odours and increasing the shelf life.

The study [21] includes formulations of a fermented milk drink made from goat's milk with various berry fillers, while goat milk produced in the Akmola region at the Zerenda farm was used, which was ozonated for 10 minutes at an ozone concentration of $80 \mathrm{mg} / \mathrm{m} 3$. In the study [22], goat's milk obtained at the Zerenda farm was used to develop a recipe for yoghurt enriched with amaranth flour. The study [23] investigated regional features of mare's milk of the Republic of Kazakhstan. According to its physicochemical and biological properties, mare's milk has a number of features that characterise it as a valuable medicinal product. The physicochemical parameters of mare's milk considerably depended on the region, the time of year, and the conditions of keeping animals. Mare's milk of Akmola district was characterised by a relatively high-fat content $(1.7 \%)$, the protein was $1.87 \%$. The lactose content in the milk of mares differed slightly by region and amounted to $5.37 \%$ for the Akmola region. Mare's milk of the Akmola region had a relatively high vitamin A content - 30.8 micrograms, whereas, in other regions, this indicator was considerably lower (18.3 - 26.3 micrograms). An advantageous difference between the mare's milk samples is that they had a high PUFA content with mainly $\omega-6$ and $\omega-3$ fatty acids. All the samples studied were collected from mares of the Jabe breed. According to the owners, the animal's diet consisted of wild and forage plants; after milking, the milk was stored at room temperature. In general, in all regions, the productivity of dairy mares was 3.6-8.5 litres per day. Thus, samples of mare's milk collected from all regions of Kazakhstan can be considered suitable for processing.

\section{DISCUSSION}

Milk producers are primarily interested in increasing the mass of milk produced by a cow per unit of time. Nevertheless, a commercial milk processor is primarily interested in the percentage composition of milk, since deviations in the composition of milk must be compensated for in the production of dairy products, for example, cheese, since a constant ratio between certain components of milk must be observed in the finished product. The focus should be on the technological properties of milk, namely the possibility of its effective use for processing into certain products: fermented milk products, cheese, butter [24]. The composition of milk may vary considerably. A great practical interest in the composition of milk has led to many studies aimed at clarifying the various factors responsible for differences in the composition. Variations in the fat content in milk have been studied to a greater extent than other components due to the greater economic value of fat. The variability of milk 
composition among cows of the same breed depends partly on hereditary differences and environmental factors. When studying the physiological and environmental factors affecting milk composition, it is necessary to consider possible changes in milk yield. An increase in fat content may reflect a decrease in milk yield rather than an increase in fat secretion itself. The picture may be incomplete if the percentage of components will be analysed without considering milk yield [9].

It is known that the chemical composition of milk varies inversely with the amount of milk produced. Thus, seasonal changes in the fat content in milk can be considered a dilution of fat due to an increase in milk production by a cow. However, the protein content in milk is subject to fewer seasonal variations [25] - the study [24] also revealed an inverse relationship between milk yield and its fat and protein content: the lower the milk yield, the higher the fat and protein content in it. According to the presented results of the work performed in the Akmola region, it is also possible to note a tendency to increase milk's fat content with a decrease in milk yield. Studies show a reduction in feed per 1 litre of milk in highly productive cows. In addition to that, there is no clearly expressed relationship between the volume of feed consumed and the amount of milk produced; an increase in concentrate consumption does not lead to a rise in the volume of milk produced. The effect of total cow feed intake on the composition and volume of milk produced without changing the diet was investigated [25]. In general, overfeeding does not lead to a change in milk composition. The main result of overfeeding is the fattening of the animal. In addition to that, underfeeding leads to a decrease in milk yields and depletion of the accumulated fat reserves of the animal.

In some cases, a decrease in milk yield may be accompanied by an increase in fat content, although the overall secretion of fat remains constant. Often underfeeding occurs at the beginning of lactation. This is accompanied by a noticeable increase in fat percentage in milk, especially if the cow is fat. The yield of milk fat increases. In certain instances, there is a slight decrease in the content of skimmed solids in milk. There is a decrease in the content of protein and lactose with underfeeding. A lot of work has been done to determine the effect of the cows' diet on milk composition. In particular, the effect of the introduction of coarse feed into the diet on the content of fat, protein, and minerals in milk was investigated. It was discovered that a considerable decrease in the fat content in milk (about $0.5 \%$ ) could be observed due to small changes in milk yield when feeding cows with diets with a low content of a coarse feed. The reduction in fat content is not entirely consistent; it is more pronounced in the early stages of lactation and depends on the type of carbohydrates in the concentrate. The low content of coarse feed in cows' diet changes the processes occurring in the rumen so that less fat is synthesised. The content of skimmed milk substances did not change much with a decrease in the consumption of coarse feed [9].

The cow's body synthesises milk fat from carbohydrates with a fat-free diet, but a small increase in milk and fat yields can be obtained by directly including fat in the diet. The protein content in the diet does not have a noticeable effect on the composition of milk, although some articles indicated a slight decrease in the protein content in milk from cows on low-protein diets. In addition to that, it should be considered that in the long term, increased and reduced protein content in the diet of dairy cows leads to diseases and reduced productivity [13]. There are pretty pronounced and characteristic differences in milk composition from cows of different breeds, which is especially clearly reflected in the fat content of milk. Differences in the fat content in milk are more pronounced between Guernsey and Jersey cows, to a lesser extent between the Holstein and Ayrshire breeds. Data on other milk components are not as extensive as data on fat; however, the available information indicates that the protein and lactose content of different breeds of cows varies in the same way, but to a lesser extent than the fat content (Table 6).

Table 6 The composition of milk of different breeds of dairy cows.

\begin{tabular}{lccccccc}
\hline \multicolumn{1}{c}{ Breed } & $\begin{array}{c}\text { Number of } \\
\text { cows }\end{array}$ & $\begin{array}{c}\text { Number } \\
\text { of } \\
\text { samples }\end{array}$ & $\begin{array}{c}\text { Mass } \\
\text { fraction of } \\
\text { fat, } \\
\mathbf{\%}\end{array}$ & $\begin{array}{c}\text { Mass } \\
\text { fraction of } \\
\text { protein, } \\
\text { \% }\end{array}$ & $\begin{array}{c}\text { Mass } \\
\text { fraction of } \\
\text { lactose, \% }\end{array}$ & $\begin{array}{c}\text { Mass } \\
\text { fraction } \\
\text { of ash, \% }\end{array}$ & $\begin{array}{c}\text { Mass } \\
\text { fraction of } \\
\text { dry } \\
\text { substances, } \\
\text { \% }\end{array}$ \\
\hline Holstein & 19 & 268 & $3.55 \pm 0.57$ & $3.42 \pm 0.51$ & $4.86 \pm 0.27$ & $0.68 \pm 0.04$ & $12.50 \pm 1.04$ \\
Brown Swiss & 17 & 428 & $4.01 \pm 0.60$ & $3.61 \pm 0.53$ & $5.04 \pm 0.39$ & $0.73 \pm 0.05$ & $13.41 \pm 0.95$ \\
Ayrshire & 14 & 208 & $4.14 \pm 0.54$ & $3.58 \pm 0.34$ & $4.69 \pm 0.47$ & $0.68 \pm 0.04$ & $13.11 \pm 0.96$ \\
Jersey & 15 & 199 & $5.18 \pm 0.80$ & $3.86 \pm 0.43$ & $4.94 \pm 0.36$ & $0.70 \pm 0.04$ & $14.69 \pm 1.11$ \\
Guernsey & 16 & 321 & $5.19 \pm 0.71$ & $4.02 \pm 0.46$ & $4.91 \pm 0.30$ & $0.74 \pm 0.03$ & $14.87 \pm 1.10$ \\
\hline
\end{tabular}

Note: Source [9]. 
Seasonal fluctuations in the composition of milk are pretty pronounced. Seasonal changes in the fat content in milk are pronounced; in winter, the fat content is higher than in summer. The content of the dry fat-free substance shows the same trend, although to a lesser extent and with much greater unevenness. The protein and mineral content are higher in winter than in summer. In the study [24] the highest dry matter content, skimmed milk powder, fat, and protein in milk was observed in winter, while in summer these indicators were the lowest. This is due to a change in the diet, namely, replacing part of the feed with greens and increasing milk yield. In the study [14] analysis of the milk of Holstein cows showed, on the contrary, a slight decrease in the fat content in milk in winter, which can be explained by the influence of diet or other factors. For example, ambient temperature has been suggested as one of the factors responsible for seasonal fluctuations in milk composition. Convincing evidence of the influence of temperature is the results of experiments in which cows were kept in facilities with controlled temperature and a diet of constant composition. These studies have shown that fluctuations in ambient temperature from $1{ }^{\circ} \mathrm{C}$ to $24^{\circ} \mathrm{C}$ do not considerably affect the milk yield or milk composition of cattle of European origin. With temperatures between $29^{\circ} \mathrm{C}$ and $41{ }^{\circ} \mathrm{C}$, the milk yield decreased, the fat content increased, the content of fat-free solids, total nitrogen, and lactose decreased. The decrease in the content of fat-free dry matter was more pronounced in the Holstein breed than in the Guernsey breed. Ambient temperatures below four ${ }^{\circ} \mathrm{C}$ caused an increase in fat content, an increase in the content of fat-free solids and total nitrogen [9].

Cow's milk contains an average of $4 \%$ fat, which $97-98 \%$ consists of triacylglycerols [7]. Milk fat can contain up to 400 different fatty acids, which are usually grouped by the saturation of their carbon chain into saturated fatty acids, monounsaturated fatty acids, and polyunsaturated fatty acids. Cow's milk usually contains $70 \%$ SFA, $25 \%$ MUFA, and 5\% PUFA. From the standpoint of human health, attention has recently been paid to fatty acids C12:0, C14:0, and C16:0, which increase the deposition of fat on the walls of blood vessels, along with fatty acids with odd and branched chains which are capable of suppressing cancer. Dietary intake of fats rich in cismonounsaturated fatty acids and long-chain polyunsaturated fatty acids plays a role in preventing heart disease. As a result, there is an increased interest in changing the fatty acid composition of milk fat. Many factors can influence the fatty acid composition of cattle milk, including breed, lactation stage, maintenance conditions, diet composition, season, geographical location, access to fresh pastures, type of pasture, feeding with grain and oilseeds, the addition of oil to feed. Studies have shown the possibility of changing the fatty acid profile of milk fat [26]. The analysis of the fatty acid profile of milk fat from Holstein cows of the Akmola region was conducted in the study [14] showed an increased content of monounsaturated and polyunsaturated fatty acids in comparison with the milk of Simmental cows.

A very important indicator of quality for milk processors is the content of somatic cells and the total number of bacteria. In addition to that, this indicator of milk quality is difficult to maintain in conditions when most of the milk coming for processing is produced in private farms. The quality of milk in households is generally poor due to the lack of necessary sanitary conditions for keeping livestock and veterinary measures. In addition to that, the availability of demand and a good purchase price, along with control, should encourage private households to improve their quality [8]. An increase in the number of somatic cells in raw milk is associated with mastitis, an inflammatory reaction of the breast, most often due to bacterial infection. The total number of somatic cells in the collected milk is usually used to indicate milk quality, herd health. Mastitis infection directly affects the composition and milk yield of infected cows. From an economic standpoint, an increase in the number of somatic cells in the milk is associated with a decrease in herd yields and farmers' profits. From the standpoint of product quality, an increase in the number of somatic cells is associated with an altered milk composition, increased enzyme activity, and an increased risk of product defects. The native milk protease plasmin plays an essential role in this process. Plasmin actively hydrolyses $\beta$-casein and $\alpha$-caseins. Casein is the main milk protein involved in the coagulation process in producing cheese and fermented milk products.

Hydrolysis of $\beta$-casein by plasmin leads to the formation of $\gamma$-casein and proteosopeptones, which are lost with whey during the production of quarg and cheese. Both plasmin and plasminogen are heat-resistant and can withstand pasteurisation $\left(72{ }^{\circ} \mathrm{C} / 15 \mathrm{~s}\right)$; after treatment $\left(138^{\circ} \mathrm{C} / 2 \mathrm{~s}\right)$, up to $40 \%$ of activity remains, and only a temperature above $147^{\circ} \mathrm{C}$ leads to complete inactivation. Although plasmin is considered the main cause of milk protein breakdown, other proteases in milk have been identified as having activity against caseins. In addition to proteolysis, increased lipolysis in milk, presumably due to lipoprotein lipase activity, is also associated with mastitis and a high content of somatic cells in raw milk. An increase in the content of free fatty acids due to lipolysis directly affects the taste of milk and dairy products (for example, rancidity and related defects) [7]. With a high content of proteolytic enzymes in milk, the reported protein content in milk is increased since the protein content in milk is mostly determined by the Kjeldahl method by multiplying the total nitrogen content in the sample by a coefficient equal to 6.38. This analysis may show a high protein content in milk since part of the nitrogen is in milk in non-protein nitrogen. This is due to the gradual decomposition of proteins in raw chilled milk by native milk proteases and proteolytic enzymes of extraneous microflora during storage at low 
temperatures (from $3{ }^{\circ} \mathrm{C}$ to $5{ }^{\circ} \mathrm{C}$ ). An increase in the content of $\gamma$-casein and the protease peptone fraction negatively affects rennet coagulability, synergetic properties of protein clots, the thermal stability of milk, and its other technological properties. Typically, $\gamma$-casein is $3 \%$ of the casein content in milk, but its content can greatly increase (up to 10\%) with late lactation and mastitis [27].

In the study [24] milk in terms of somatic cell content and bacterial contamination had the lowest quality in spring, which was associated with climatic changes, that is, with the temperature and humidity regime. The content of somatic cells in the milk of Holstein cows of the Akmola region was analysed in the study [14] ranged from 344 thousand $/ \mathrm{cm}^{3}$ up to 260 thousand $/ \mathrm{cm} 3$, the highest value was in the winter, while the norm is not more than 7.5 thousand $* 10^{5}$ for raw milk and not more than $5 * 10^{5}$ for milk intended for the production of baby food, cheese, and autoclaved milk, according to the Technical Regulations of the Customs Union "On the safety of milk and dairy products" [18]. There are increased requirements for milk intended for processing into cheese. According to the method of coagulation of milk protein, three main groups of cheese can be distinguished: rennet coagulation (up to $75 \%$ of all cheeses produced), acid coagulation, and combined thermal acid coagulation. Milk for processing into cheese by rennet coagulation must be microbiologically pure. This is because during rennet coagulation, the use of harsh pasteurisation regimes is not allowed. Usually, the pasteurisation mode is $72{ }^{\circ} \mathrm{C}$ in $15 \mathrm{~s}$. An increase in milk exposure at temperatures above $70^{\circ} \mathrm{C}$ causes a deterioration in the rennet coagulation. The cheese obtained from pasteurised milk usually has an increased moisture content, a crumbly consistency, and high losses of protein and fat with whey. Milk for processing into cheese must also have a certain concentration of fat and casein; the ratio of these components is an important parameter affecting cheese quality [27].

Because there is a shortage of raw milk in the Republic of Kazakhstan, O. V. Koltyugina et al. [15] used the method of thermal acid deposition for the production of cheese. At the same time, several farms were selected as milk suppliers to ensure proper primary processing of milk and stability of the chemical composition. A common feature of the technology of all acid coagulation products is that an acid-induced gel is formed at the initial stage, which is then further processed. Heat treatment of milk is one of the most important processes affecting the texture of acid coagulation gels. Milk for certain fresh sour cheese, such as quarg, undergoes considerable heat treatment. The inclusion of whey protein in fresh cheese is an important aspect of its production due to the increased yield [28]. Another important test that should be conducted for milk intended for the production of cheese and fermented milk products is the presence of acid-inhibiting substances. While minor changes in the chemical composition can affect the quality of the final product and the economy of the process, the presence of antibiotics in a batch of milk intended for fermentation with sourdough leads to a complete loss of this batch.

\section{CONCLUSION}

One of the priorities in ensuring the country's food security is milk production and its processing. Akmola region is one of the main agricultural and industrial regions of the Republic of Kazakhstan. The government pays great attention to the development of rural industry, allocating subsidies for livestock breeding and reducing the cost of milk and dairy food production. Milk production in the Akmola region in 2020 reached 402.7 thousand tons. The main problem of the dairy industry remains the lack of a raw material base. The main producers of milk are the households of the population. This problem is associated with the inconstancy of the bulk milk quality coming to the Akmola region's enterprises in terms of microbiological quality and the number of somatic cells. Other countries solve this problem using a system of incentives for enterprises that supply milk of consistently good quality according to these indicators to processing plants.

To increase the workload of the Akmola region dairy enterprises with raw materials, the number of dairy cows is increased, and recipes for dairy products using other types of milk - goat and mare's milk are developed. While milk producers are interested in obtaining high milk yields, processors, firstly, evaluate the technological qualities of milk, its suitability for the production of certain types of goods. Milk indicators such as the content of fat, protein, and lactose, the absence of antibiotics and adulterating substances, low levels of somatic cells and microbiological indicators are crucial. The analysis of milk samples produced in the Akmola region confirms its suitability for processing in terms of protein and fat content somatic cell content. Analysis of the fatty acid composition of milk fat from Holstein cows of the Akmola region showed an increase in the proportion of monoand polyunsaturated fatty acids in the composition of milk fat triglycerides, which is beneficial to human health. 


\section{REFERENCES}

1. Azretbergenova, G. Zh., Syzdykova, A. O., \& Bimendeev, B. (2021). Ensuring food security of the Republic of Kazakhstan in the context of COVID-2019. In Agricultural Market Problems (No. 2, pp. 21-30). Kazakh Research Institute of Agricultural Economics and Rural Development

2. On amendments to the resolution of the akimat of Akmola region No. A-2/50 "On approval of the amount of subsidies in the field of animal husbandry". (2021). Retrieved from https://www.gov.kz/memleket/entities/aqmola-ush/documents/details/161435?lang=ru

3. Report on the implementation of budget programs of the Department of Agriculture of Akmola region for 2020. (2021). Retrieved from https://www.gov.kz/memleket/entities/aqmolaush/documents/details/156152?lang=ru

4. Report of akim of Akmola region Ermek Marzhikpayev "On the results of socio-economic development of Akmola region for 2020 and main tasks for 2021". (2021). Retrieved from https://cutt.ly/JWTZbOx.

5. Processing enterprises of Akmola region. (2021). Retrieved from https://www.gov.kz/memleket/entities/aqmola-ush/documents/details/112451?lang=ru

6. Shunekeyeva, A. A., Alimardanova, \& M. K., Loskutova, G. A. (2018). Prospects for expanding the range of national Kazakh dairy products through the use of goat milk. In V. A. Wagner, \& E. S. Dikalova (Eds.), Modern problems of technology and technology of food production: Materials of the XIX International Scientific and Practical Conference Barnaul (pp. 264-266). Polzunov Altai State Technical University.

7. Murphy, S. C., Martin, N. H., Barbano, D. M., \& Wiedmann, M. (2016). Influence of raw milk quality on processed dairy products: How do raw milk quality test results relate to product quality and yield? In Journal of Dairy Science (Vol. 99, No. 12, pp. 10128-10149). Elsevier. https://doi.org/10.3168/jds.2016-11172

8. Nassyrkhanova, B. K., \& Belgibayeva, A. S. (2020). Milk and dairy products market in Akmola region of Kazakhstan. Problems of AgriMarket (No. 4, pp. 125-132). Kazakh RI of AIC Economy and Rural Development. https://doi.org/10.46666/2020-4-2708-9991.15

9. Jenness, R., \& Patton, S. (2018). Principles of dairy chemistry. Agri Horti Press.

10. On the production of raw cow's milk by agricultural producers of Akmola region. (2020). Retrieved from https://stat.gov.kz/api/getFile/?docId=ESTAT384914

11. Socio-economic development of agriculture in Akmola region in 2021. (2021). Retrieved from https://www.gov.kz/memleket/entities/aqmola-ush/documents/details/134394?lang=ru

12. Alimzhanov, B. O., Alimzhanova, L. V., Bekkozhin, A. Zh., Bostanova, S. K., Sheiko, \& Yu. N. (2014). Milk productivity, reproductive ability and morphofunctional properties of the udder of first-generation Holstein heifers. In Herald of Science of S. Seifullin Kazakh Agro Technical University (Vol. 3, No. 82, pp. 41-46). Bulletin of Science of the S. Seifullin Kazakh Agrotechnical University.

13. Aitmukhanbetov, D. K., Alentaev, A. S., \& Shamshidin, A. S. (2018). Milk urea content in dairy herds of Akmola region, the Republic of Kazakhstan. In R. V. Nekrasov., E. N. Delyagina, \& S. A. Nikitin (Eds.), Fundamental and applied feeding aspects agricultural animals: Materials of the International Scientific and Practical Conference (pp. 18-20). Federal Research Center for Animal Husbandry named after Academy Member L.K. Ernst.

14. Khastaeva, A. Zh., Zhamurova, V. S., Mamaeva, L. A., Kozhabergenov, A. T., Karimov, N. Zh., \& Muratbekova, K. M. (2021). Quality indicators of milk of Simmental and Holstein cows in different lactation seasons. In Veterinary World (Vol. 14, No. 4, pp. 956-963). Veterinary World.

15. Koltyugina, O. V., Loskutova, G. A., Dubinets, I. M., \& Alekseenko, I. V. (2013). Assessment of raw milk in the Akmola region of the Republic of Kazakhstan. In Polzunovsky Bulletin (Vol. 4, No. 4, pp. 143-145). Polzunov Altai State Technical University.

16. Shaimerdenova, D. A., Chakanova, J. M., Iskakova, D. M., Sarbasova, G. T., Esmambetov, A. A., \& Bekbolatova, M. B. (2020). Fermented milk products with extruded grain bases. In Proceedings of VSUET (Vol. 82, No. 4, pp. 179-187). VSUET. https://doi.org/10.20914/2310-1202-2020-4-179-187

17. ST RK 1733-2015 "Milk and dairy products. General technical conditions". (2017). Retrieved from https://online.zakon.kz/Document/?doc_id=32459980\#pos=38;-60.

18. Technical regulations of the Customs Union "On the safety of milk and dairy products". (2013). Retrieved from https://docs.cntd.ru/document/499050562

19. Zhakupova, G. N., Sagandyk, A. T. (2020). Development of technology of yoghurt by using acid whey. News of the National Academy of Sciences of the Republic of Kazakhstan (Vol. 4, No. 442, pp. 51-57). D.V. Sokolsky Institute of Fuel, Catalysis and Electrochemistry. https://doi.org/10.32014/2020.2518$\underline{1491.64}$ 
20. Shunekeyeva, A. A. (2020). Research of preferences of consumers of dairy products in the Akmola region. In Eurasia Journal of BioSciences (No. 14, pp. 6687-6690). Foundation for Enviromental Protection and Research.

21. Shunekeyeva, A. A., Alimardanova, M., \& Majorov, A. A. (2021 a). Chemical composition, texture and sensory evaluation of yogurts supplemented with amaranth flour. In American Journal of Animal and Veterinary Sciences (Vol. 16, No. 2, pp. 136-143). Science Publications. https://doi.org/10.3844/ajavsp.2021.136.143

22. Shunekeyeva, A. A., Alimardanova, M. K., \& Majorov, A. A. (2021 b). Fruit-berry fillers in the production of Kazakh national fermented milk drinks. In News of the National Academy of Sciences of the Republic of Kazakhstan (Vol. 1, No. 445, pp. 139-144). D.V. Sokolsky Institute of Fuel, Catalysis and Electrochemistry.

23. Sinyavskiy, Yu. A., Berdygaliev, A. B., Deripaskina, Ye. A., Kucherbayeva, M. M., Ibraimov, Y. S., Nurushev, M. Zh., \& Tuigunov, D. N. (2020). Regional features of the composition and properties of mares milk. Bulletin of the Orenburg Scientific Center of the Ural Branch of RAS (No. 2, pp. 1-17). Orenburg Scientific Center of the Ural Branch of RAS.

24. Harlap, S.Yu., Gorelik, A.S., Kvarditsky, E.V., Vinogradova, N.D., Batalov, A.S., \& Tamaev, S.A. (2020). Technological properties of cow's milk depending on the season of the year. In IOP Conference Series: Earth and Environmental Science (Vol. 613, article number 012047). IOP Science. https://doi.org/10.1088/1755$\underline{1315 / 613 / 1 / 012047}$

25. Bousbia, A., Ghozlane, F., Benidir, M., \& Belkheir, B. (2013). Quantitative and qualitative response of dairy production of cattle herds to husbandry practices. In African Journal of Agricultural Research (Vol. 8, No. 45, pp. 5622-5629). Academic Journals. https://doi.org/10.5897/AJAR2013.7477

26. Hanuš, O., Križova, L., Samkova, E., Špicka, J., Kucera, J., Klimešova, M., Roubal, P., \& Jedelska, R. (2016). The effect of cattle breed, season and type of diet on the fatty acid profile of raw milk. In Archives Animal Breeding (No. 59, pp. 373-380). Copernicus. https://doi.org/10.5194/aab-59-373-2016

27. Fox, P. F., Uniacke-Lowe, T., McSweeny, P. L. H., \& O’Mahony, J. A. (2015). Dairy chemistry and biochemistry. Springer.

28. McSweeney, P. L. H., Fox, P. F., Cotter, P. D., \& Everett, D.W. (2017). Cheese: Chemistry, physics and microbiology. Academic Press.

\title{
Funds:
}

This research received no external funding.

\section{Acknowledgments:}

\section{Conflict of Interest:}

The authors declare no conflict of interest.

\section{Ethical Statement:}

This article does not contain any studies that would require an ethical statement.

\author{
Contact Address: \\ *Zhanara Nurtayeva, S. Seifullin Kazakh Agrotechnical University, Department of Marketing, Zhenis Ave., 62, \\ 010011, Nur-Sultan, Republic of Kazakhstan, \\ Tel.: +77172317547 \\ E-mail: zh.nurtayeva7520@tanu.pro \\ ORCID: https://orcid.org/0000-0001-5299-7410
}

Corresponding author: *

(C) 2022 Authors. Published in www.potravinarstvo.com the official website of the Potravinarstvo Slovak Journal of Food Sciences, owned and operated by the Association HACCP Consulting, Slovakia, www.haccp.sk. The publisher cooperate with the SLP London, UK, www.slplondon.org the scientific literature publisher. This is an Open Access article distributed under the terms of the Creative Commons Attribution License https://creativecommons.org/licenses/by/4.0, which permits unrestricted use, distribution, and reproduction in any medium provided the original work is properly cited. 